\title{
Paspanguwa Herbal Formula, a Traditional Medicine of Sri Lanka: A Critical Review
}

\author{
H.K.S. De Zoysa ${ }^{1}$, Pavithra N. Herath ${ }^{2}$, Raymond Cooper ${ }^{3}$ and Viduranga Y Waisundara ${ }^{1 *}$ \\ ${ }^{1}$ Technology Degree Programme, Faculty of Applied Sciences, Rajarata University of Sri Lanka, Mihintale, Sri Lanka \\ ${ }^{2}$ Department of Animal Science, Uva Wellassa University, Sri Lanka \\ ${ }^{3}$ Department of Applied Biology \& Chemical Technology, The Hong Kong Polytechnic University, Hong Kong
}

Submission: June 12, 2017; Published: August 16,2017

*Corresponding author: Viduranga Y Waisundara, Technology Programme, Faculty of Applied Sciences, Rajarata University of Sri Lanka, Mihintale, Sri Lanka, Tel: 9425 2266130; Fax: 9425 2266130; Email: viduranga@gmail.com

\begin{abstract}
The Sri Lankan traditional medicinal system reaches back over 3000 years. The traditional medicines of Sri Lanka have gained an impressive level of acceptance over their more 'Western' counterparts, despite the lack of substantial scientific evidence. This is due mainly to cultural, folklore, habitual use, and ethological reasoning. One well respected traditional formula, the 'paspanguwa' herbal formulation has found its way to modern times, due to its repositioning with a modern outlook in the current consumer market. However, scientific investigations on its effectiveness against disease conditions are scarce, but this void has not posed any threat to its position as an herbal beverage, which imparts health and wellness aspects in general. The 'paspanguwa' formulation consists of five ingredients, namely Ginger (Zingiber officinale), 'Pathpadagam' (Hedyotis corymbosa), 'Katuwalbatu' (Solanum xanthocarpum), 'Veniwalgata' (Coscinium fenestratum) and Coriander (Coriandrum sativum). In some instances other herbs such as 'Thippili' (Piper longum), Thai eggplant (Solanum melongena), Black pepper (Piper nigrum), Wishnukranthiya (Evolvulus alsinoides) and Pawatta (Justicia adhatoda) may also be used. Nevertheless, for potential acceptance of the herbal formula on a global basis, much more research is needed and the scientific voids should be sufficiently filled in order to substantiate its standing as an effective medicine even for minor ailments such as the common cold.
\end{abstract}

Keywords: Ayurveda; Coriander; Paspanguwa; Sri Lanka; Thai eggplant

\section{Traditional Medicines in Modern Times}

With the advent of a myriad of diseases for which the pharmaceutical industry has been unable to find effective remedies, the quest for complementary and alternative medicines - especially of traditional medicinal origin, has been on the rise. Coupled with this shortcoming of the pharmaceutical industry, a significant lag in productivity exists even though 'pharma' companies have invested prodigious amounts in novel discovery technologies, such as structure-based drug design, combinatorial chemistry, high-throughput screening (HTS) and genomics, which were sold on the promise of improving productivity [1]. The use of synthetic, or rather 'Western' medicine only started to gain popularity in the late nineteenth century; before that, herbs were primarily used as remedies in the treatment of a wide range of disease conditions [2]. Most of these traditional medicinal plants are readily available and are cheap; hence it is easily accessible and easily consumable. Additionally, due to their more 'natural' predisposition, when administered at the correct dosage, the side-effects from consuming these remedies are minimal [3] However, these may not be the true reasons why complementary and alternative herbal medicines are more popular among patients worldwide. A study by Astin [4] revealed that the majority of users of complementary and alternative medicines - whether it be herbal or not, appear to be doing so, not so much as a result of being dissatisfied with conventional medicine, but rather because they find these alternatives to be more congruent with their own values, beliefs and philosophies towards health and life.

Nevertheless, traditional medicines compete with science and the hurdles they pose for their proper recognition as valid remedies. For instance, as stated by Fontanarosa and Lundberg [5], 'there is no alternative medicine; there is only scientificallyproven, evidence-based medicine, for which the scientific evidence is lacking'. Sanctioning and obtaining support for the propagation of traditional medicinal remedies within the scientific frame of investigation has been scarce, although the use of many traditional medicinal products by indigenous cultures 
for centuries, and the belief that they are safe and beneficial, represent the opportunities for further improving health and well-being and for preventing and treating disease [6]. However, within the modern process and procedures of drug development and clinical research, substantiating the efficacy of these traditional remedies is a complex endeavor in general. Despite the constant battle between traditional medicinal practices and science, only few studies have nevertheless shown that traditional medicinal systems should not be taken lightly even though the lengthy procedure for providing evidence of efficacy may demonstrate the already-proven benefits of traditional medicines [7-9].

\section{The Traditional Medicinal System of Sri Lanka}

The Sri Lanka Ayurvedic medicinal system has gradually developed towards approaching the scientific realms for recognition, but nevertheless, has a wide appreciation and consumerism among its natives. This system goes back 3000 years or more - according to local myths and legends which are transmitted verbally [10]. In the present scenario, it is divided into four main domains, namely Siddha and Ayurveda, both of which originated in India, Unani - A Perso-Arabic traditional medicine system, and an indigenous medicine system in Sri Lanka, known as 'Deshiya Chikitsa' [10]. In Sri Lanka, about $60-70 \%$ of the rural population use Ayurvedic medicines for curing and prevention of diseases. Most of these medicines are consumed in the form of concoctions or decoctions - methods of preparation, which continue to be practiced in modern times. When it comes to the local population, despite being a developing country, there is a significant rate of urbanization in Sri Lanka, which comes hand-in-hand with an increased literacy level and a wider exposure to science and technology [11]. Thus, traditional Ayurvedic medicines of Sri Lanka have gained acceptance over their more 'Western' counterparts, despite the lack of substantial scientific evidence.

Before describing in detail about the 'paspanguwa' herbal formula, it is firstly necessary to introduce the Sri Lankan medicinal system in brief, which in its nature is extremely diversified and has not lost its appeal despite the 3000-year-old history $[10,12,13]$.Many of the traditional medicinal recipes were either verbally handed down across generations, or written down in the native languages - most commonly Sinhala. Overall, written documents, which are intact, or translations of these documents, are scarce. In many instances, there are no fixed formulae for the medicines, since the dosages and combinations are customized according to the physiology of the diseased. This is mostly owing to the philosophy of targeting the whole body not each organ in isolation [13]. Thus, the holistic approach, which is commonly observed in other traditional medicinal systems, is found in the Sri Lankan traditional medicinal system as well. Most of the traditional medicines in Sri Lanka are based on natural remedies from trees and plants and their appendages, such as the bark, flowers, leaves, fruits, seeds, stems, root, rhizomes and bulbs
$[10,14,15]$. Although the scientific elucidations were absent during the inception of this medicinal system, the medicinal value of plants are currently well recognized because of the presence of many natural bioactive substances, which are capable of disease prevention [16-19]. These compounds are normally synthesized due to secondary metabolic activities [20-23]. Possibly owing to the existence of a variety of bioactive compounds, the traditional medicine system of Sri Lanka always believed complex disease are best treated with complex combinations of botanical and non-botanical remedies [24]. This could be the reason why herbal combinations such as the 'paspanguwa' are deemed more effective than a single herb-based remedy.

Introduction to 'Paspanguwa'

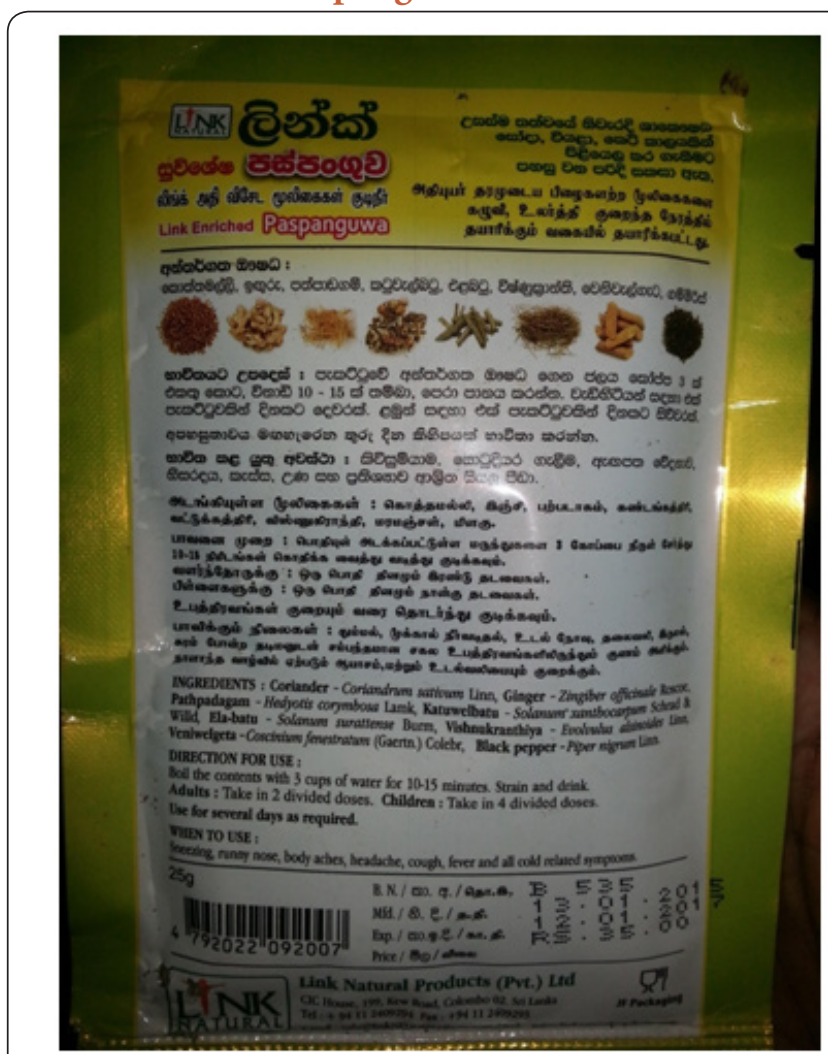

Figure 1: List of ingredients mentioned in the packaging containing the 'paspanguwa' herbal formula which can be bought off supermarket shelves in Sri Lanka.

The 'paspanguwa' traditional medicinal formula can be obtained as air-tight sachets or packets as an over-the counter medicine in pharmacies and supermarkets. The ailments, for which this can be used as per the instructions in the packaging, are colds, coughs, headaches, fever, and overall body aches. Although the herbal formulation itself has not been clinically evaluated, its constituents possess significant evidence as to their respective efficacies against a myriad of disease conditions. 'Paspanguwa' is commonly consumed as an herbal tea preparation. The name, which means five portions in the vernacular language of Sinhala, is made by the combination of five main herbs. The five ingredients, which make up the formula commonly, consist of Ginger (Zingiber officinale), 'Pathpadagam' (Hedyotis corymbosa), 
'Katuwalbatu' (Solanum xanthocarpum), 'Veniwalgata' (Coscinium fenestratum) and Coriander (Coriandrum sativum). In some instances other herbs such as 'Thippili' (Piper longum), Thai eggplant (Solanum melongena), Black pepper (Piper nigrum), Wishnukranthiya (Evolvulus alsinoides) and Pawatta (Justicia adhatoda) may also be used. Figure 1 shows a commercially available 'paspanguwa' package, and the ingredients used. The resulting herbal tea from this decoction is bitter in taste, thus, it is often taken together with sugar or juggery. To date, there has been only one in vitro study performed to explore the antioxidant and starch hydrolyses inhibitory properties of one form of the 'paspanguwa' herbal formula [25]. However, it should be noted that the major constituents in these herbsin this herbal formula have been systematically studied for their efficacy against a variety of ailments, thus it may be deemed reasonable to review existing scientific material on these individual herbs. Overall, the purpose of this review is to (1) describe the formula (2) assess the 'paspanguwa' herbal formula and its constituents and (3) promote the argument whether scientific validation is truly required for traditional medicinal recipes, such as these, which have gained so much popularity even without the scientific rigor.

Therapeutic Effects of the Constituent Herbs of ohe 'Paspanguwa' Formula

As previously mentioned, there are five 'major' constituents in the 'paspanguwa' formula, followed by minor ones which are incorporated primarily to boost the strength and effectiveness of the major components. The 'major' herbs are those, which are considered to contain the highest ability to prevent ailments such as coughs, colds, fever, and body aches. The rest do not necessarily target these diseases; however, as per traditional medicinal records, they are able to prevent these ailments when used in combination with another 'major' herb, rather than in isolation [10] (Figure 2).
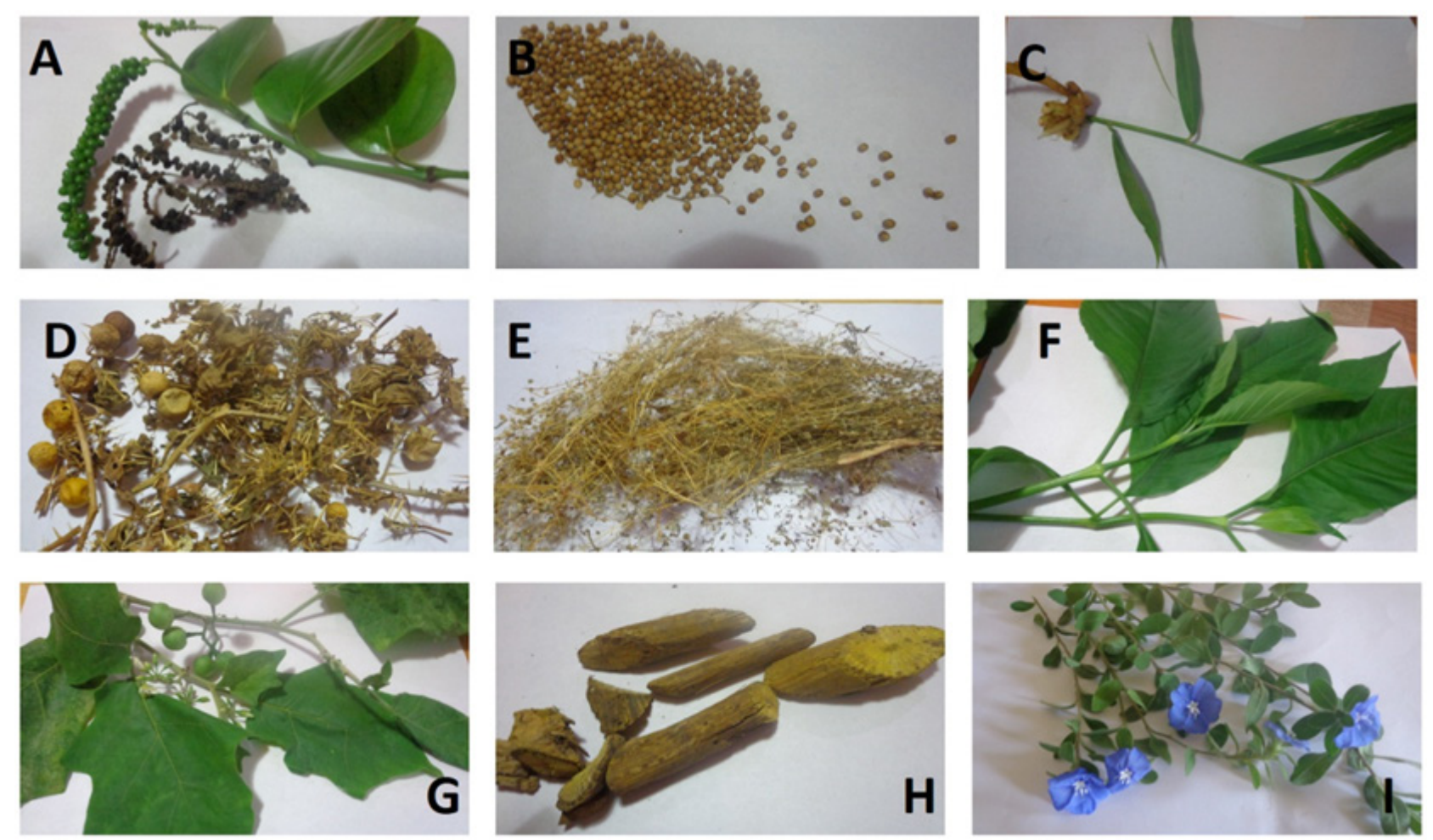

Figure 2: Images of the major and minor ingredients used for the preparation of the 'paspanguwa': (A) Black Pepper (B) Coriander seeds (C) Ginger plant with its rhizome (D) Dried Katuwelbatu (E) Dried Pathpadagam (F) Fresh leaves of Pawatta (G) Thai Eggplant (H) Dried veniwelgata root bark (I) Vishnukranthiya plant.

\section{Ginger (Zingiber officinale)}

Ginger rhizomes are commonly used as a spice for preparing baked products, soups, pickles, puddings, and fermented beverages such as beer. In addition, it is used to obtain essential oil and oleoresin, which are internationally commercialized for use in the food and pharmaceutical industries [26]. In traditional medicinal the dried ginger rhizomes are widely used as a home remedy to act against diseases such as vomiting, nausea and morning sickness during pregnancy, and also are used in the treatment of heart attack and stroke [26]. In Ayurveda, ginger is also mentioned as an appetiser and could be used as an ointment for pains and for the treatment of digestive disorders and arthritis $[27,28]$. Due to the versatility of ginger and its usage in many ailments, it is known as a universal treatment $[28,29]$. Dried ginger rhizomes, which have been pulverized into powder is one of the five major ingredients of the 'paspanguwa' formula. 


\section{Pathpadagam (Hedyotis corymbosa)}

This is a very common medicinal herb used in traditional as well as modern medicinal systems throughout the world. The plant is used as a treatment for skin aliments, appendicitis, viral infections, acne, venomous bites and eye disease [30]. A decoction of the aerial part of this plant is used in the treatment of diseases such as a cough, bronchitis, necrosis, leprosy, giddiness, jaundice and nervous depression [31]. Additionally, the herb is also known to possess anti-inflammatory, antioxidant, hepatoprotective and fever-reducing effects [32,33]. The leaves of the plant are known to possess iridoid glucosides in the form of anthraquinones and triterpenoids [34-38]. The leaves and stems of this herb are incorporated into the 'paspanguwa' recipe as one of the five major ingredients.

\section{Katuwalbatu (Solanum xanthocarpum)}

This herb is commonly used in the traditional medicinal system in Sri Lanka for a variety of ailments. It is known to contain a high amount of alkaloids and flavonoids [39]. It is known for its anti-asthmatic, hepato protective, hypoglycemic, antiinflammation, and anti hyperlipidemic properties and it is used for the treatment of fever, asthma, bronchitis, urinary disease, heart diseases and reduce and physical pain [40]. Solasodine is the primary bioactive compound in S. xanthocarpum, which possesses the antipyretic property [41-43]. Dried berries of this herb are incorporated into the 'paspanguwa' formula as one of the five major ingredients.

\section{Veniwalgata(Coscinium fenestratum)}

This is a flowering woody climber with a high amount of antioxidant [44], anti-diabetic [45] and anti-cancer effects [46]. Berberine is one of the major bioactive compounds found in the stem of $C$. fenestratum, which is known to possess a wide range of pharmacological activities. [45] In addition, a small portion of protoberberine is also present $[47,48]$. C. fenestratum which is commonly used in Western medicine as an anti-cancer [46], antioxidant [44], hypoglycemic [49] and antibacterial agent [50]. In the traditional 'paspanguwa' the dried stem of this plant is used as one of the five major ingredients.

\section{Coriander (Coriandrum sativum)}

Coriander is one of the most common herbs used in many traditional systems to treat many disorders [51]. In traditional medicinal systems, coriander is given to reduce the pain of rheumatism by pounding the seeds and combining them with hot water to make a paste and applied topicallyon the affected area [51]. The seeds are used for health attributes such as improving diseases related to the gastro-intestinal tract and diabetes [5256]. Al-Mofleh et al. [57] have demonstrated that Coriander seed powder protects the gastric mucosa in rats from ethanol-induced damage and also inhibit the formation of ulcers in rats. Another study demonstrated that the extract made from Coriander seeds has been used as a protective agent for gastric mucosa [58].
The powder of dried Coriander seeds is typically added to the 'paspanguwa' herbal formula as one of the five major ingredients.

\section{Thippili' (Piper longum)}

$P$. longum is a medicinal herb commonly used in traditional medicine and has a distinct odor and a pungent bitter taste. It is known as a remedy against gonorrhea, menstrual pain, viral hepatitis, tuberculosis, chronic malaria, sleeping problems, chronic bronchitis, asthma, chronic gut-related pain paralysis of the tongue, diseases of the spleen, cough, tumors and arthritis [59-62]. It is able to directly affect the central nervous system $[59,63]$. In traditional Ayurvedic medicine, this is considered as a good rejuvenator $[60,64-76]$. The dried fruit of $P$. longum is sometimes added to the 'paspanguwa' formulation, and is not considered as one of the five major ingredients but rather a complementary agent.

\section{Thai eggplant (Solanum melongena)}

Thai egg plant is cultivated worldwide as a vegetable crop and is rich in polyphenols [77]. It is rich in other nutrients, essentially minerals and vitamins as well as proteins, riboflavin, thiamine iron, calcium, nicotinemide, carbohydrate, vitamin C, fibre, fat and carotenes $[78,79]$. It is typically used in the treatment of skin infections, gonorrhea, diabetes, rheumatic disease and swollen joint pains $[78,80]$. The dried vegetable is sometimes added to the 'paspanguwa' herbal formula as a complementary boosting agent.

\section{Black pepper (Piper nigrum)}

P. nigrum is a widely used spice, consisting of piperine as the main bioactive compound. Other biologically active compounds in $P$. nigrum include monoterpenes, sesquiterpenes, curcumin and vasicine [81]. It has immunomodulatory, anti-carcinogenic, anti-asthmatic, stimulatory, hepatoprotective, anti-inflammatory, antimicrobial spices, anti-ulcer activities, antioxidant and bio transformative effects, and is also known to enhance the absorption of drugs such as rifampicin, sulphadiazine, tetracyline, and phenytoin [81-84]. In the Sri Lankan traditional medicinal system, P. nigrum is used to treat chills, rheumatism, flu, muscular aches, colds, exhaustion and fevers as well as to increase circulation of blood, increase the flow of saliva, stimulate the appetite, and to encourage peristalsis $[81,85,86]$. P. nigrum is also used as a boosting agent in the 'paspanguwa' herbal formula.

\section{Wishnukranthiya (Evolvulus alsinoides)}

E. alsinoides is a medicinal herb, which is well documented in the Sri Lankan traditional medicinal system as having immunomodulatory, cytoprotective, adaptogenic, antiamnesic properties and antioxidant properties [87-90]. This herb is used to promote adaptogenic, anti-phlogistic, antipyretic, antiseptic, aphrodisiac, febrifuge, stomachic, tonic and vermifuge effects [91-94]. E. alsinoides is used as a supplementary herb in the 'paspanguwa' herbal formula. 


\section{Pawatta (Uusticia adhatoda)}

J. adhatoda is a medicinal shrub widespread throughout the tropical regions of South-East Asia [95]. Its leaves and roots are commonly used in the Sri Lankan traditional medicinal system, which are known to possesstwo major alkaloids, vasicine and vasicinone along with some minor components such as vasicoline $[96,97]$. The extract of the leaves of $J$. adhatoda has the ability to act as an anti-spasmodic, fever-reducing, antiinflammatory, anti-bleeding, bronchodilatory, anti-diabetic, disinfectant, anti-jaundice, oxytocic and anti-helminticagent $[97,98]$. In the traditional medicinal system of Sri Lanka, this is used to treat cold, cough, pneumonia, fever, jaundice, joint pain, catarrh, whooping cough, asthma and tuberculosis [97]. Although J. adhatoda is used only as a supplementary herb in the 'paspanguwa' formula, it is used as the major ingredient in many other traditional medicinal recipes of Sri Lanka

\section{Traditional Methods of Preparation and Consumption of the 'Paspanguwa'}

There are several ways of preparing the 'paspanguwa' by locals as well as by traditional medicinal practitioners, where in all methods, addition of water and heat is the most frequent way of obtaining the extract. Cold water may be added to the ingredients until boiling temperature is reached, or boiled water may be added to the ingredients and left in a closed container (typically, made from clay) for 10-15mins. The duration of boiling or exposure to boiled water may vary, mostly depending on the combination of ingredients used. The steam generated during the boiling process may also be used for inhalations to obtain relief from coughs and colds. The extract is recommended to be used at least 2-3 times per day, depending on the severity of the ailment. The traditional method of preparation has not been adequately documented and is passed down orally from one generation to another. Nevertheless, as one of the more 'simpler' forms of herbal formula in the traditional medicinal system of Sri Lanka, consultations with traditional medicinal practitioners revealed that the method of preparation does not vary all that much, other than the duration of boiling.

Quality of Preparation, Standards, and Dosages for Modern Times

One aspect of the 'paspanguwa' formula, if it were to be sent out to a global market, would be to enhance the quality of preparation, determine the standards and dosages a practice which has not been fully ascertained by modern day manufacturers of traditional medicines. The need for these aspects, especially Total Quality Management (TQM) has been emphasized in a recent publication by Cooper [99]. While this paper focuses on Traditional Chinese Medicine (TCM), there is a need for all traditional medicinal systems to adapt to a more scientific means of verification, so that the health claims can be substantiated, including the 'paspanguwa' formula. Especially for Europe and the United States, acceptability of traditional herbal medicines requires evaluation of dosages to assure safety and efficacy [100]. At this time, only a traditional medicinal practitioner's word defines the currently accepted dosage of one 'portion' of each of the major herbs to varying amounts of the minor herbs, where 'portion' is simply a term of measurement of strength. For scientific investigations, researchers also need to bear in mind that the 'paspanguwa' formula is a combination of herbs, and thus, a reductionist approach may not work in fully determining its effectiveness. For this, modern advents such as use of a biomarker, linking a biological effect to a chemical marker and standardizing the levels of bio-actives, will go a long way to an improved quality product. Finally, newer processes such as systems biology, metabolomics and chemo metrics may be used to evaluate the biological responses of the formula more effectively [101-103], leading to a clinical trial.

\section{Conclusion}

In conclusion, herbal formula such as the 'paspanguwa' has been accepted by local people in Sri Lanka, despite the absence of systematic scientific elucidations, owing to its extensive history of application, as well as the effectiveness for several ailments across generations. It is available as a commercial product, which can be bought off the shelf and thus, has found acceptance into the modern consumer market while obtaining a similar status as a typical pain-killer. To provide a more valueadded effectiveness, scientific investigations need to be carried out, so that its applications are more disease-specific - especially pandemics such as diabetes, cardiovascular disease, and cancer, given the recently discovered ability of the formula to possess antioxidant and starch hydrolase inhibitory activities. The safety and efficacy of the formula needs to be scientifically established, if it is to be promoted into the global market, where regions such as Europe and the United States might require rigorous examination of this aspect. On a more traditional and cultural note, the 'paspanguwa' story also infers the importance of interconnectivity of medicines, recognizing the ingredients used in the formulation and the potency of the individual medicines have combined into a unique remedy, which can be used for many disease conditions as well as for maintaining overall health and wellness. Given certain shortcomings of 'western' medicines, the holistic approach is an aspect, which can be learned and adapted, for physiological systems operate in harmony, and thus, offers these medicines and remedies to be a part of our wellness arsenal.

\section{Conflicts of Interest}

The authors report no conflicts of interest, financial or otherwise.

\section{Acknowledgement}

Dr. Waisundara wishes to acknowledge the support rendered by Mrs. Nilakshi Jaywardena and Miss Mindani Watawana who were former Research Assistants of the National Institute of 
Fundamental Studies in Kandy, Sri Lanka in composing this manuscript.

\section{References}

1. Ashburn TT, Thor KB (2004) Drug repositioning: identifying and developing new uses for existing drugs. Nature reviews Drug discovery 3(8): 673-683.

2. Prakash J (2010) Chemical composition and antioxidant properties of ginger root (Zingiber officinale). Journal of Medicinal Plants Research 4(24): 2674-2679.

3. Krishnaswamy K (2008) Traditional Indian spices and their health significance. Asia Pacific Journal of Clinical Nutrition 17(S1): 265-268.

4. Astin JA (1998) Why patients use alternative medicine: results of a national study. Journal of the American Medicinal Association 279(19): 1548-1553.

5. Fontanarosa PB, Lundberg GD (1998) Alternative medicine meets science. Journal of the American Medicinal Association 280(18): 16181619.

6. Engel LW, Straus SE (2002) Development of therapeutics: opportunities within complementary and alternative medicine. Nature Reviews Drug Discovery 1(3): 229-237.

7. Ou B, Huang D, Hampsch-Woodill M, Flanagan JA (2003) When east meets west: the relationship between yin-yang and antioxidationoxidation. The FASEB journal 17(2): 127-129.

8. Chau P-L (2000) Ancient Chinese had their fingers on the pulse. Nature 404(6777): 431-431.

9. Ko KM, Mak DH, Chiu PY, Poon MK (2004) Pharmacological basis of 'Yang-invigoration'in Chinese medicine. Trends in pharmacological sciences 25(1): 3-6.

10. Ediriweera E, Ratnasooriya W (2009) A review on herbs used in treatment of diabetes mellitus by Sri Lankan ayurvedic and traditional physicians. AYU (An international quarterly journal of research in Ayurveda) 30(4): 373.

11. Waisundara VY, Watawana MI (2014) Evaluation of the antioxidant activity and additive effects of traditional medicinal herbs from Sri Lanka. Australian Journal of Herbal Medicine 26(1): 22-28.

12. Broom A, Wijewardena K, Sibbritt D, Adams J, Nayar K (2010) The use of traditional, complementary and alternative medicine in Sri Lankan cancer care: results from a survey of 500 cancer patients. Public Health 124(4): 232-237.

13. Weragoda P (1980) The traditional system of medicine in Sri Lanka. Journal of ethnopharmacology 2(1): 71-73.

14. Arseculeratne SN, Gunatilaka AL, Panabokke RG (1985) Studies on medicinal plants of Sri Lanka. Part 14: toxicity of some traditional medicinal herbs. Journal of Ethnopharmacology 13(3): 323-335.

15. Arseculeratne SN, Gunatilaka AL, Panabokke RG (1981) Studies on medicinal plants of Sri Lanka: occurrence of pyrrolizidine alkaloids and hepatotoxic properties in some traditional medicinal herbs. Journal of ethnopharmacology 4(2): 159-177.

16. Edeoga H, Okwu D, Mbaebie B (2005) Phytochemical constituents of some Nigerian medicinal plants. African journal of biotechnology 4(7): 685-688.

17. Mahesh B, Satish S (2008) Antimicrobial activity of some important medicinal plant against plant and human pathogens. World journal of agricultural sciences 4(supplement 1): 839-843.

18. Samy RP, Ignacimuthu S (2000) Antibacterial activity of some folklore medicinal plants used by tribals in Western Ghats of India. Journal of Ethnopharmacology 69(1): 63-71.
19. Palombo EA, Semple SJ (2001) Antibacterial activity of traditional Australian medicinal plants. Journal of ethnopharmacology 77(2): 151-157.

20. Yadav R, Agarwala M (2011) Phytochemical analysis of some medicinal plants. Journal of phytology 3(12).

21. Brown JE, Rice-Evans CA (1998) Luteolin-rich artichoke extract protects low density lipoprotein from oxidation in vitro. Free radical research 29(3): 247-255.

22. Krings U, Berger R (2001) Antioxidant activity of some roasted foods. Food Chemistry 72(2): 223-229.

23. Ali SS, Kasoju N, Luthra A, Singh A, Sharanabasava H, et al. (2008) Indian medicinal herbs as sources of antioxidants. Food Research International 41(1): 1-15.

24. Raskin I, Ribnicky DM, Komarnytsky S, Ilic N, Poulev A, et al. (2002) Plants and human health in the twenty-first century. TRENDS in Biotechnology 20(12): 522-531.

25. Jayawardena N, Watawana MI, Waisundara VY Antioxidant and starch hydrolase inhibitory activities of the 'Paspanguwa' herbal formula of Sri Lanka. Chiang Mai Journal of Science:accepted, in press.

26. Kamaliroosta Z, Kamaliroosta L, Elhamirad A (2013) Isolation and identification of ginger essential oil. Journal of Food Biosciences and Technology 2(3): 73-80.

27. Malhotra S, Singh AP (2003) Medicinal properties of ginger (Zingiber officinale Rosc.). Natural Product Radiance 2(6): 296-301.

28. Tapsell LC, Hemphill I, Cobiac L, Sullivan DR Fenech M, et al. (2006) Supplement-Health benefits of herbs and spices: The past, the present, the future. Medical Journal of Australia 185(4): S4-S24.

29. Giri J, Sakthidevi T, Meerarani S (1984) Effect of ginger on serum cholesterol levels. Indian Journal of Nutrition and Dietetics 12(21): 433-437.

30. Sasikumar J, Maheshu V, Aseervatham G, Darsini D (2010) In vitro antioxidant activity of Hedyotis corymbosa (L.) Lam. aerial parts. Indian Journal of Biochemistry \& Biophysics 47(1): 49-52.

31. Warrier P, Nambiar V, Ramankutty C (1995) Indian Medicinal Plants: A Compendium of 500 Species. Orient Longman 3 (222-228.

32. Mishra K, Dash AP, Swain BK, Dey N (2009) Anti-malarial activities of Andrographis paniculata and Hedyotis corymbosa extracts and their combination with curcumin. Malaria Journal 8(26): 1-9.

33. Noiarsa P, Ruchirawat S, Otsuka H, Kanchanapoom T (2008) Chemical constituents from Oldenlandia corymbosa L. of Thai origin. Journal of Natural Medicines 62(2): 249-250.

34. Takagi S, Yamaki M, Masuda K, Nishihama Y, Sakina K (1981) Studies on the herb medical materials used for some tumors. II. On the constituents of Hedyotis corymbosa Lam (author's transl). Yakugaku zasshi: Journal of the Pharmaceutical Society of Japan 101(7): 657-659.

35. Hideaki Otsuka, Kayoko Yoshimura, Kazuo Yamasaki MCC (1991) Isolation of 10-0-acyl iridoid glucosides from a Philippine medicinal plant, Oldenlandia corymbosa L.(Rubiaceae). Chemical and Pharmaceutical bulletin 39(8): 2049-2052.

36. Banerjee A, Sane R, Mangaonkar K, Shailajan S, Deshpande A, et al. (2006) Quantitation of oleanolic acid in Oldenlandia corymbosa L. whole-plant powder by high-performance thin-layer chromatography. JPC-Journal of Planar Chromatography-Modern TLC 19(107): 68-72.

37. Dung LK, Van Sung T, Dien PG (2002) Two anthraquinones from Hedyotis corymbosa and Hedyotis diffusa. Tap Chi Hoa Hoc 40(3): 6668.

38. Chen W, Zou S-q, LI K-q (2005) Extracting and Identifying Ursolic Acid from Hedyotis Corymbosa Lam. Journal of Yichun University. 
39. Kumar S, Sharma U, Sharma A, Pandey A (2012) Protective efficacy of Solanum xanthocarpum root extracts against free radical damage: phytochemical analysis and antioxidant effect. Cellular and Molecular Biology 58(1): 171-178.

40. Reddy N, Reddy R (2014) Solanum xanthocarpum chemical constituents and medicinal properties: A review. Scholar Academic Journal of Pharmacy 3(2): 146-149.

41. Jain J (1980) A clinical trial of kantakari (Solanum xanthocarpum) in cases of tamak swasa (some respiratory diseases). Journal of Research in Ayurveda and Siddha 1(3): 447-460.

42. Govindan S, Viswanathan S, Vijayasekaran V, Alagappan R (1999) A pilot study on the clinical efficacy of Solanum xanthocarpum and Solanum trilobatum in bronchial asthma. Journal of ethnopharmacology 66(2): 205-210.

43. Singh OM, Singh T (2010) Phytochemistry of Solanum xanthocarpum: an amazing traditional healer. Journal of Scientific \& Indutrial Research 69: 732-740.

44. Punitha I, Rajendran K, Shirwaikar A, Shirwaikar A (2005) Alcoholic stem extract of Coscinium fenestratum regulates carbohydrate metabolism and improves antioxidant status in streptozotocinnicotinamide induced diabetic rats. Evidence-Based Complementary and Alternative Medicine 2(3): 375-381.

45. Neethu P, Haseena P, Thomas RS, Goveas SW, Abraham A (2014) Antioxidant properties of Coscinium fenestratum stem extracts on Streptozotocin induced type 1 diabetic rats. Journal of Applied Pharmaceutical Science 4(1): 29-32.

46. Tungpradit R, Sinchaikul S, Phutrakul S, Wongkham W, Chen ST (2010) Anti-cancer compound screening and isolation: coscinium fenestratum, Tinospora crispa and Tinospora cordifolia. Chiang Mai Journal of Science 37(3): 476-488.

47. Malhotra S, Taneja S, Dhar K (1989) Minor alkaloid from Coscinium fenestratum. Phytochemistry 28(7): 1998-1999.

48. Pinho PM, Pinto MM, Kijjoa A, Pharadai K, Díaz JG et al. (1992) Protoberberine alkaloids from Coscinium fenestratum. Phytochemistry 31(4): 1403-1407.

49. Shirwaikar A, Rajendran K, Punitha I (2005) Antidiabetic activity of alcoholic stem extract of Coscinium fenestratum in streptozotocin-nicotinamide induced type 2 diabetic rats. Journal of Ethnopharmacology 97(2): 369-374.

50. Nair G, Narasimhan S, Shiburaj S, Abraham T (2005) Antibacterial effects of Coscinium fenestratum. Fitoterapia 76(6): 585-587.

51. Wangensteen H, Samuelsen AB, Malterud KE (2004) Antioxidant activity in extracts from coriander. Food chemistry 88(2): 293-297.

52. Gray AM, Flatt PR (1999) Insulin-releasing and insulin-like activity of the traditional anti-diabetic plant Coriandrum sativum (coriander). British Journal of Nutrition 81(3): 203-209.

53. Cortés-Eslava J, Gómez-Arroyo S, Villalobos-Pietrini R, EspinosaAguirre JJ (2004) Antimutagenicity of coriander (Coriandrum sativum) juice on the mutagenesis produced by plant metabolites of aromatic amines. Toxicology letters 153(2): 283-292.

54. Eidi M, Eidi A, Saeidi A, Molanaei S, Sadeghipour A, et al. (2009) Effect of coriander seed (Coriandrum sativum L.) ethanol extract on insulin release from pancreatic beta cells in streptozotocin-induced diabetic rats. Phytother Res 23(3): 404-406.

55. Darughe F, Barzegar M, Sahari M (2012) Antioxidant and antifungal activity of Coriander (Coriandrum sativum L.) essential oil in cake. International Food Research Journal 19(3): 1253-1260.

56. Sunil C, Agastian P, Kumarappan C, Ignacimuthu S (2012) In vitro antioxidant, antidiabetic and antilipidemic activities of Symplocos cochinchinensis (Lour.) S. Moore bark. Food and chemical toxicology 50(5): 1547-1553.

57. Al-Mofleh I, Alhaider A, Mossa J, Al-Sohaibani M, Rafatullah S, et al.(2006) Protection of gastric mucosal damage by Coriandrum sativum L. pretreatment in Wistar albino rats. Environmental Toxicology and Pharmacology 22(1): 64-69.

58. Hedges L, Lister C (2007) Nutritional attributes of herbs, crop and food. Research Confidential Report, A report presented for Horticulfare New Zealand 42.

59. Sunila E, Kuttan G (2004) Immunomodulatory and antitumor activity of Piper longum Linn. and piperine. Journal of ethnopharmacology 90(2): 339-346.

60. Kumar S, Kamboj J, Sharma S (2011) Overview for various aspects of the health benefits of Piper longum linn. fruit. Journal of acupuncture and meridian studies 4(2): 134-140.

61. Rastogi R, Mehrotra B (1993) BN Compendium of Indian Medicinal plants Central DrugResearch Institute Lucknow \& NISC. New Delhi 4.

62. Singh YN (1992) Kava: An overview. Journal of ethnopharmacology 37(1): 13-45.

63. Stöhr JR, Xiao PG, Bauer R (2001) Constituents of Chinese Piper species and their inhibitory activity on prostaglandin and leukotriene biosynthesis in vitro. Journal of Ethnopharmacology 75(2): 133-139.

64. Anuradha V, Srinivas P, Madhusudana Rao J (2004) Isolation and synthesis of isodihydropiperlonguminine. Natural product research 18(3): 247-251.

65. Pradeep C Kuttan G (2002) Effect of piperine on the inhibition of lung metastasis induced B16F-10 melanoma cells in mice. Clinical \& experimental metastasis 19(8): 703-708.

66. Natarajan KS, Narasimhan M, Shanmugasundaram KR, Shanmugasundaram E (2006) Antioxidant activity of a saltspice-herbal mixture against free radical induction. Journal of ethnopharmacology 105(1): 76-83.

67. Koul IB, Kapil A (1993) Evaluation of the liver protective potential of piperine, an active principle of black and long peppers. Planta medica 59(05): 413-417.

68. Kumar S, Arya P, Mukherjee C, Singh BK, Singh N, et al (2005) Novel aromatic ester from Piper longum and its analogues inhibit expression of cell adhesion molecules on endothelial cells. Biochemistry 44(48): 15944-15952.

69. Tripathi D, Gupta N, Lakshmi V, Saxena K, Agrawal A (1999) Antigiardial and immunostimulatory effect of Piper longum on giardiasis due to Giardia lamblia. Phytotherapy Research 13(7): 561-565.

70. Ali MA, Alam N, Yeasmin M, Khan A, Sayeed M, et al. (2007) Antimicrobial screening of different extracts of Piper longum Linn. Res J Agri Biol Sci 3(60): 852-857.

71. Iwashita M, Saito M, Yamaguchi Y, Takagaki R, Nakahata N (2007) Inhibitory effect of ethanol extract of Piper longum L. on rabbit platelet aggregation through antagonizing thromboxane A2 receptor. Biological and Pharmaceutical Bulletin 30(7): 1221-1225.

72. Vedhanayaki G, Shastri GV, and Kuruvilla A (2003) Analgesic activity of Piper longum Linn. root. Indian J Exp Biol 41(6): 649-651

73. Choochote W, Chaithong U, Kamsuk K, Rattanachanpichai E, Jitpakdi A, et al. (2006) Adulticidal activity against Stegomyia aegypti (Diptera: Culicidae) of three Piper spp. Revista do Instituto de Medicina Tropical de São Paulo 48(1): 33-37.

74. Kim KS, Kim JA, Eom SY, Lee SH, Min KR, et al. (2006) Inhibitory effect of piperlonguminine on melanin production in melanoma B16 cell line by downregulation of tyrosinase expression. Pigment cell research 19(1): 90-98. 
75. Lee SA, Hwang JS, Han XH, Lee C, Lee MH, et al. (2008) Methylpiperate derivatives from Piper longum and their inhibition of monoamine oxidase. Archives of pharmacal research 31(6): 679-683.

76. Shoji N, Umeyama A, Saito N, Takemoto T, Kajiwara A, et al. (1986) Dehydropipernonaline, an amide possessing coronary vasodilating activity, isolated from Piper iongum L. Journal of pharmaceutical sciences 75(12): 1188-1189.

77. Mennella G, Rotino GL, Fibiani M, D’Alessandro A, Francese G, et al (2010) Characterization of health-related compounds in eggplant (Solanum melongena L.) lines derived from introgression of allied species. Journal of agricultural and food chemistry 58(13): 7597-7603.

78. Igwe S, Akunyili D, Ogbogu C (2003) Effects of Solanum melongena (garden egg) on some visual functions of visually active Igbos of Nigeria. Journal of ethnopharmacology 86(2): 135-138.

79. Tindal HD (1965) Fruits and Vegetables in West Africa, 2nd ed. Oxford. University Press, Place, City, Country 105.

80. Kwon Y-I, Apostolidis E, and Shetty K (2008) In vitro studies of eggplant (Solanum melongena) phenolics as inhibitors of key enzymes relevant for type 2 diabetes and hypertension. Bioresource Technology 99(8): 2981-2988.

81. Meghwal M and Goswami T (2013) Piper nigrum and piperine: an update. Phytotherapy Research 27(8): 1121-1130.

82. Yang YC, Lee SG, Lee HK, Kim MK, Lee SH, et al. (2002) A piperidine amide extracted from Piper longum L. fruit shows activity against Aedes aegypti mosquito larvae. Journal of agricultural and food chemistry 50(13): 3765-3767.

83. Bai Y-F and Xu H (1999) Protective action of piperine against experimental gastric ulcer. Acta Pharmacologica Sinica 21(4): 357-359.

84. Wu H (2007) Isolation and characterization of natural products from ginger and Allium ursinum. ProQuest, Place, City.

85. Pruthi JS (1993) Major spices of India. Crop management and postharvest technology. Major spices of India. Crop management and postharvest technology.

86. Sharon M (2002) Herb-Drug Interaction Handbook. Church Street Books: NY 12

87. Bhatnagar M, Shukla S, Jain S, and Mundra A (2000) Cytoprotective effects of Shankhpushpi an E. alsenoids preparation on hippocampal cells in mice. Indian Drugs 37(6): 280-285.

88. Lilly G, Dev K, Chanda S, Srivastava K, Sawhney R, et al. (2003) Immunomodulatory effects of agents of plant origin. Biomedicine \& pharmacotherapy 57(7): 296-300.

89. Nahata A, Patil U, and Dixit V (2009) Anxiolytic activity of Evolvulus alsinoides and Convulvulus pluricaulis in rodents. Pharmaceutical biology 47(5): 444-451.
90. Siripurapu KB, Gupta P, Bhatia G, Maurya R, Nath C, et al. (2005) Adaptogenic and anti-amnesic properties of Evolvulus alsinoides in rodents. Pharmacology Biochemistry and Behavior 81(3): 424-432.

91. Gomathi D, Kalaiselvi M, Ravikumar G, Devaki K, Uma C (2015) GC-MS analysis of bioactive compounds from the whole plant ethanolic extract of Evolvulus alsinoides (L.) L. Journal of food science and technology 52(2): 1212-1217.

92. Austin DF (2008) Evolvulus alsinoides (Convolvulaceae): an American herb in the old World. Journal of ethnopharmacology 117(2): 185-198.

93. Auddy B, Ferreira M, Blasina F, Lafon L, Arredondo F, et al. (2003) Screening of antioxidant activity of three Indian medicinal plants, traditionally used for the management of neurodegenerative diseases. Journal of Ethnopharmacology 84(2): 131-138.

94. Singh A (2008) Review of Ethnomedicinal Uses and Pharmacology of Evolvulus alsinoides Linn. Ethnobotanical leaflets 2008(1): 100.

95. Chakraborty A and Brantner A (2001) Study of alkaloids from Adhatoda vasica Nees on their antiinflammatory activity. Phytotherapy Research 15(6): 532-534.

96. Gulfraz M, Ahmad A, Asad MJ, Afzal U, Imran M, et.al (2011) Antidiabetic activities of leaves and root extracts of Justicia adhatoda Linn against alloxan induced diabetes in rats. African Journal of Biotechnology 10(32): 6101-6106.

97. Dhankhar S, Kaur R, Ruhil S, Balhara M, Dhankhar S, et al. (2011) A review on Justicia adhatoda: A potential source of natural medicine. African Journal of Plant Science 5(11): 620-627.

98. Maurya S, Singh D (2010) Quantitative analysis of total phenolic content in Adhatoda vasica Nees extracts. International Journal of PharmTech Research 2(4): 2403-2406.

99. Cooper R (2017) TCM Needs TQM. Journal of Complementary Medicine \& Alternative Healthcare 2(3): 1-3.

100.Briggs JP, Killen J (2013) Perspectives on complementary and alternative medicine research. Jama 310(7): 691-692.

101. American Association for the Advancement of Science (2014) The Art and Science of Traditional Medicine Part 1: TCM Today-A Case for Integration. Science 346(6216): 1569-1569.

102. American Association for the Advancement of Science (2015) The Art and Science of Traditional Medicine Part 2: Multidisciplinary Approaches for Studying Traditional Medicine. Science 347: 337-337.

103. American Association for the Advancement of Science (2015) The Art and Science of Traditional Medicine Part 3: The Global Impact of Traditional Medicine. Science 350: 871-871.

\section{Your next submission with Juniper Publishers} will reach you the below assets

- Quality Editorial service

- Swift Peer Review

- Reprints availability

- E-prints Service

- Manuscript Podcast for convenient understanding

- Global attainment for your research

- Manuscript accessibility in different formats

( Pdf, E-pub, Full Text, Audio)

- Unceasing customer service

Track the below URL for one-step submission https://juniperpublishers.com/online-submission.php 